Article

\title{
Occurrence of Thermophilic Microorganisms in Different Full Scale Biogas Plants
}

\author{
Ivan Kushkevych ${ }^{1, * \mathbb{D}}$, Jiří Cejnar ${ }^{1}$, Monika Vítězová ${ }^{1}$, Tomáš Vítěz ${ }^{2}$, Dani Dordević ${ }^{3}$ (D) \\ and Yannick J. Bomble ${ }^{4}$ \\ 1 Department of Experimental Biology, Faculty of Science, Masaryk University, 62500 Brno, Czech Republic; \\ 451355@mail.muni.cz (J.C.); vitezova@sci.muni.cz (M.V.) \\ 2 Department of Agricultural, Food and Environmental Engineering, Faculty of AgriSciences, Mendel \\ University, 61300 Brno, Czech Republic; tomas.vitez@mendelu.cz \\ 3 Department of Plant Origin Foodstuffs Hygiene and Technology, Faculty of Veterinary Hygiene and Ecology, \\ University of Veterinary and Pharmaceutical Sciences, 61242 Brno, Czech Republic; \\ dani_dordevic@yahoo.com \\ 4 Bioscience Center, National Renewable Energy Laboratory, 16253 Denver West Parkway, \\ Golden, CO 80401, USA; Yannick.Bomble@nrel.gov \\ * Correspondence: kushkevych@mail.muni.cz; Tel.: +420-549-495-315
}

Received: 27 November 2019; Accepted: 30 December 2019; Published: 31 December 2019

check for updates

\begin{abstract}
Background: In recent years, various substrates have been tested to increase the sustainable production of biomethane. The effect of these substrates on methanogenesis has been investigated mainly in small volume fermenters and were, for the most part, focused on studying the diversity of mesophilic microorganisms. However, studies of thermophilic communities in large scale operating mesophilic biogas plants do not yet exist. Methods: Microbiological, biochemical, biophysical methods, and statistical analysis were used to track thermophilic communities in mesophilic anaerobic digesters. Results: The diversity of the main thermophile genera in eight biogas plants located in the Czech Republic using different input substrates was investigated. In total, 19 thermophilic genera were detected after $16 \mathrm{~S}$ rRNA gene sequencing. The highest percentage (40.8\%) of thermophiles was found in the Modrice biogas plant where the input substrate was primary sludge and biological sludge $(50 / 50, \mathrm{w} / \mathrm{w} \%)$. The smallest percentage $(1.87 \%)$ of thermophiles was found in the Čejč biogas plant with the input substrate being maize silage and liquid pig manure $(80 / 20, \mathrm{w} / \mathrm{w} \%)$. Conclusions: The composition of the anaerobic consortia in anaerobic digesters is an important factor for the biogas plant operator. The present study can help characterizing the impact of input feeds on the composition of microbial communities in these plants.
\end{abstract}

Keywords: renewable energy; biogas; Illumina sequencing; thermophilic microorganisms; anaerobic digesters

\section{Introduction}

Anaerobic digestion is one of the technologies that can process and reduce biodegradable waste, thus limiting its environmental impact. Anaerobic processes are effective tools to reduce pollution and they fully meet cleaner energy production objectives. It has been used for wastewater treatment and more recently, for processing biodegradable industrial and agricultural wastes [1-5]. Anaerobic processes occur naturally in wetlands, swamps, and in the digestive tracts of ruminants [6]. Anaerobic microorganisms were also discovered in landfills where they degrade biodegradable municipal waste. The product of anaerobic metabolism is biogas [7,8], which is classified as a source of renewable energy [9]. During the anaerobic process, biochemical degradation of organic polymers to methane 
$\left(\mathrm{CH}_{4}\right)$ and carbon dioxide $\left(\mathrm{CO}_{2}\right)$ occurs [10-13]. The major components of biogas are $\mathrm{CH}_{4}(55 \%$ vol$70 \% \mathrm{vol})$ and $\mathrm{CO}_{2}(30 \% \mathrm{vol}-45 \% \mathrm{vol})[14-16]$. Anaerobic microorganisms are responsible for establishing a stable environment at different stages of biogas production $[7,8,12]$.

Thermophilic microorganisms live at high temperatures $50-122^{\circ} \mathrm{C}$. Most of them belong to the domain of Archaea [17]. This group of microorganisms can be classified, according to their optimal growth temperatures, as thermophiles $\left(50-64^{\circ} \mathrm{C}\right)$, extremophiles $\left(65-79{ }^{\circ} \mathrm{C}\right)$ and hyperthermophiles $\left(\geq 80{ }^{\circ} \mathrm{C}\right)$ [18]. Thermophilic microorganisms are often isolated from waste water discharge, bio waste streams, acid mine effluents as well as geothermal and volcanic areas, terrestrial hot springs, submarine hydrothermal vents, geothermally heated oil reserves and oil wells, sun-heated litter, and soils/sediments, throughout the world [19].

There are not many information about thermophilic microorganisms included in methane production and oxidation processes. It was found that mushroom compost piles contain $2 \times 10^{8}$ thermophilic methanogens per gram dry matter. The processes involved in methane oxidation are important since $90 \%$ of methane reaching atmosphere is in oxidized form [4].

The advances of thermophilic conditions in anaerobic digestion are represented by the fact that gas is formed within shorter amount of time than when anaerobic digestion is done under mesophilic conditions. Though, higher energy is necessary for the maintenance of thermophilic conditions in biogas plant reactor. The heating in digesters that are operating at mesophilic and thermophilic levels results in effective denaturation of weed seeds and also pathogens reduction. The pathogen reduction, after 20 days, is almost $100 \%$, meaning that thermophilic temperatures are of crucial importance for pathogens elimination. Other biogas plant digesters, operating at room temperatures, have much lower elimination level of pathogens [6].

It should be noted that thermophilic microorganisms may be involved in the process of methanogenesis, but their diversity in mesophilic biogas plants is still not well characterized, especially with respect to the effect of substrate variation. Additionally, the changes in the distribution of thermophiles in mesophilic conditions has never been well studied either. On the one hand, it appears that these microorganisms would not be able to grow under mesophilic conditions $\left(40-50{ }^{\circ} \mathrm{C}\right)$ as their growth would be too slow and unable to compete with mesophiles, but on the other hand, this hypothesis has never been studied in this context. Indeed, there is a lack of information about the metabolic activity of these microorganisms under mesophilic conditions and there remains a possibility that they could be involved in the process of methanogenesis. The prevalence of thermophilic populations in mesophilic biogas plants and their composition with respect to different substrate ratios has rarely been studied. This study aims at reducing this knowledge gap.

\section{Results}

Seven operating biogas plants in the Czech Republic, each using different feeds, were selected as sources of microbial consortia for further analysis. At the present time, there are working 450 agricultural biogas plants in the Czech Republic. Most of them operating at mesophilic temperature (in the vicinity of $42{ }^{\circ} \mathrm{C}$ ) to minimize high heat loss during winter time due to the low ambient temperatures. In this study, we selected plants using different operating conditions and ratios of input material. The physical and chemical properties (including: temperature, $\mathrm{pH}$, oxidation-reduction potential (ORP), total volatile solids, and gasses: $\mathrm{CH}_{4}, \mathrm{CO}_{2}$, and $\mathrm{H}_{2}$ ) of these bioreactors are shown in Figures 1-3. The data indicate that the highest temperature was measured in the Pánov reactor $\left(49^{\circ} \mathrm{C}\right)$, the lowest $\mathrm{pH}$ in the Modřice reactor ( $\mathrm{pH}: 7)$, and lowest ORP in the Bratčice reactor $(-75 \mathrm{mV})$ (Figure 1). 

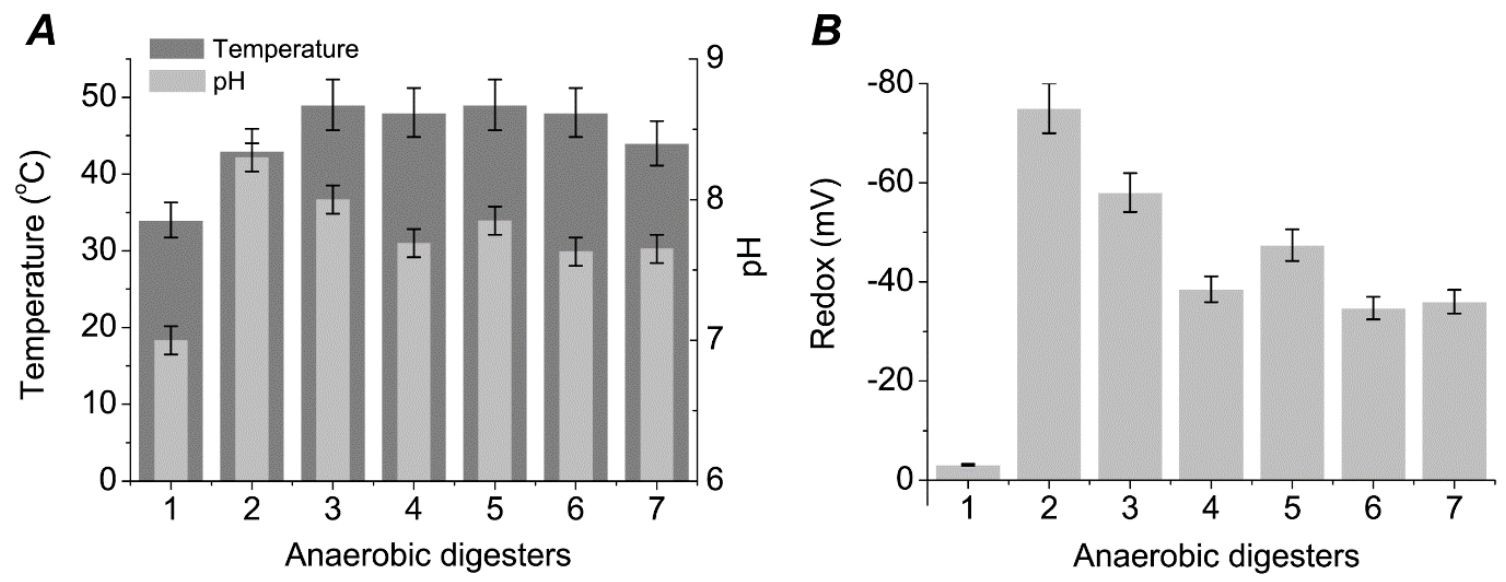

Modřice (1), Bratčice (2), Pánov (3), Úvalno (4), Horní Benešov (5), Rusín (6), Loděnice (7)

Figure 1. Physical characteristics of anaerobic digesters considered in this study $(\mathrm{M} \pm \mathrm{SE}, n=3)$ : temperature and $\mathrm{pH}(\mathbf{A})$, redox $(\mathbf{B})$.

Total and volatile solids in the different anaerobic digesters are shown in Figure 2A and are, for the most part, fairly similar with the exception of the Modrice reactor where total and volatile solids were significantly lower. The composition of the respective biogas in these reactors (for the two most dominant compounds, methane $\left(\mathrm{CH}_{4}\right)$ and carbon dioxide $\left.\left(\mathrm{CO}_{2}\right)\right)$ is shown in Figure 2B. The levels of methane and $\mathrm{CO}_{2}$ produced ranged from $47 \%$ (Modřice) to $52 \%$ (Horní Benešov) and approximately $47 \%$ for all bioreactors. Levels of hydrogen were also detected and were significantly lower in the Úvalno and Loděnice bioreactor $(0.0035 \%)$. The maximum level of hydrogen $(0.0060 \%)$ was measured in the fermenter located in Horní Benešov. The percentage of other gases detected was in the range of $1.49 \%$ in Bratčice and $4.99 \%$ in Modřice.
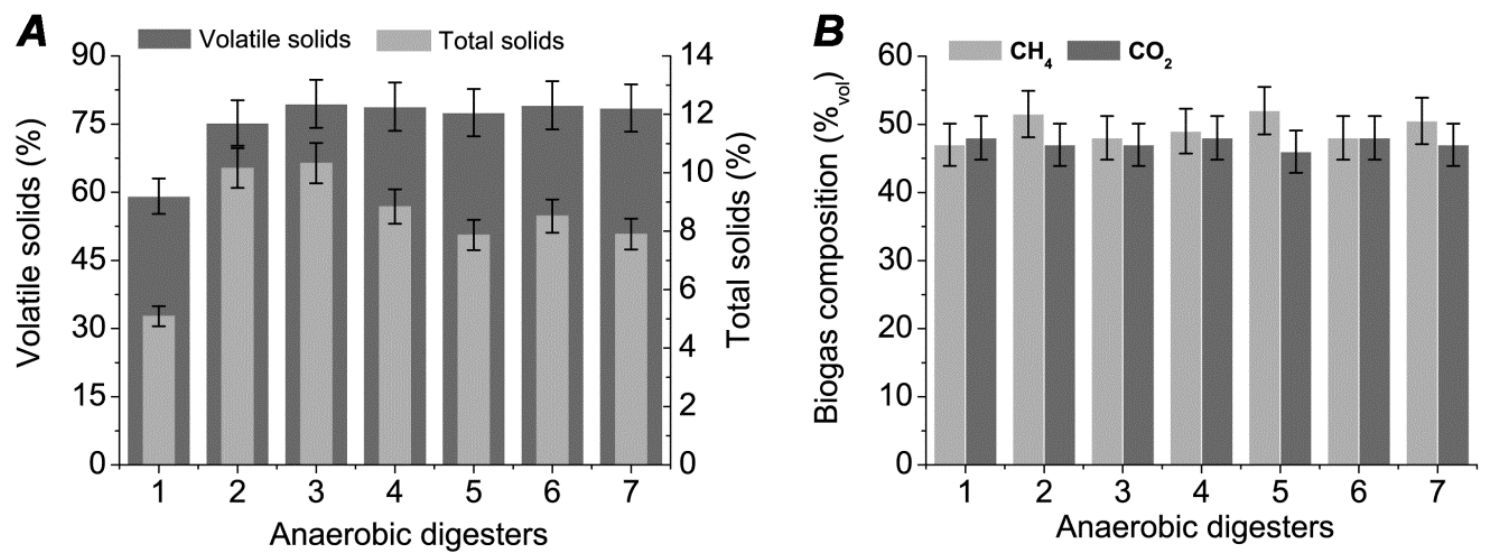

Modřice (1), Bratčice (2), Pánov (3), Úvalno (4), Horní Benešov (5), Rusín (6), Loděnice (7)

Figure 2. Amount of solids (A) and biogas production $(\mathbf{B})(\mathrm{M} \pm \mathrm{SE}, n=3)$.

We also studied the diversity of thermophilic microorganisms in these mesophilic biogas plants and evaluated the proportion of thermophiles in the microbial consortia. In all anaerobic digesters considered in this study, the proportion of thermophiles ranged from 0.06 to $1 \%$ and the composition of thermophiles was dependent on the composition of the input substrate in each biogas plant (Figure 3A). The most widespread genus among all biogas plants was Syntrophaceticus sp. and it was found in each fermenter and dominated in five of them. On the other hand, the lowest percentage and diversity of thermophilic genera (Thermogymnomonas and Syntrophaceticus) was observed in the Čejč fermenter. 
A

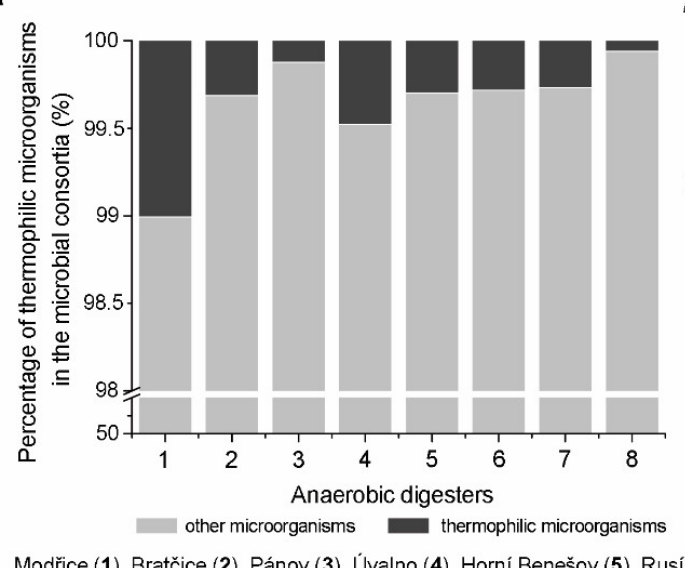

B

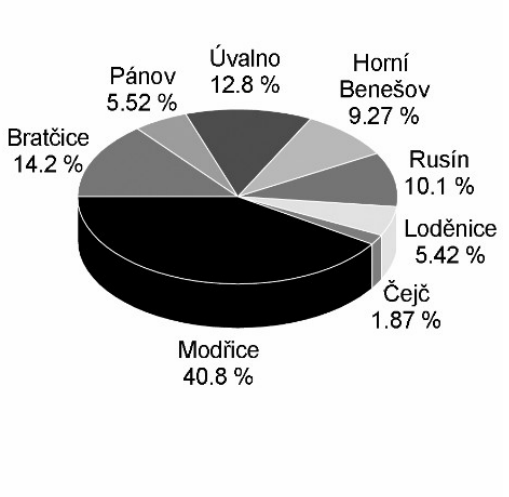

Modřice (1), Bratčice (2), Pánov (3), Úvalno (4), Horní Benešov (5), Rusín (6), Loděnice (7), Čejč (8)

Figure 3. Percentage of thermophiles in the microbial community for each reactor (A) and percentage of thermophiles observed in all anaerobic fermenters together $(\mathbf{B})$.

The greatest diversity of thermophilic microorganisms was detected in the fermenter located in Modřice (Figure 3B), probably because this anaerobic fermenter is operating in a wastewater treatment plant. The sample from Modřice contained 11 different genera of thermophiles: Thermogymnomonas (6.5\%), Thermoflavimicrobium (31\%), Thermovirga (24\%), Thermoleophilum (0.24\%), Thermanaeromonas (0.24\%), Thermomonas (2\%), Syntrophaceticus (0.97\%), Fervidobacterium (31\%), Kosmotoga (3.6\%), Caldimicrobium $(0.24 \%)$, and Oceanotoga $(0.48 \%)$. However, the dominant genera in this reactor were Thermoflavimicrobium $(31.40 \%)$ and Fervidobacterium (30.67\%). It should be noted that the Thermoflavimicrobium genus was also observed in the fermenter located in Horní Benešov but in very low abundance (1\%). The Fervidobacterium genus was also detected in Rusín (0.98\%) and Bratčice (2\%) but in low abundance as well. The following methanogenic microorganisms were found in the bioreactors (Figure 4): Methanoculleus, Thermogymnomonas, and Methanobacterium. Bioreactors in Rusín and Bratčice had mostly Methanoculleus genus (30.7\% and 29.5\%, respectively), Úvalno Thermogymnomonas genus (41.1\%), and Modřice Methanobacterium genus (81.3\%). The following methanogenic genera were also detected: Thermoplasmata, Methanospirillum, Thermoprotei, Methanobrevibacter, Methanolinea, Methanosaeta, Methanimicrococcus, though not in significant amounts.
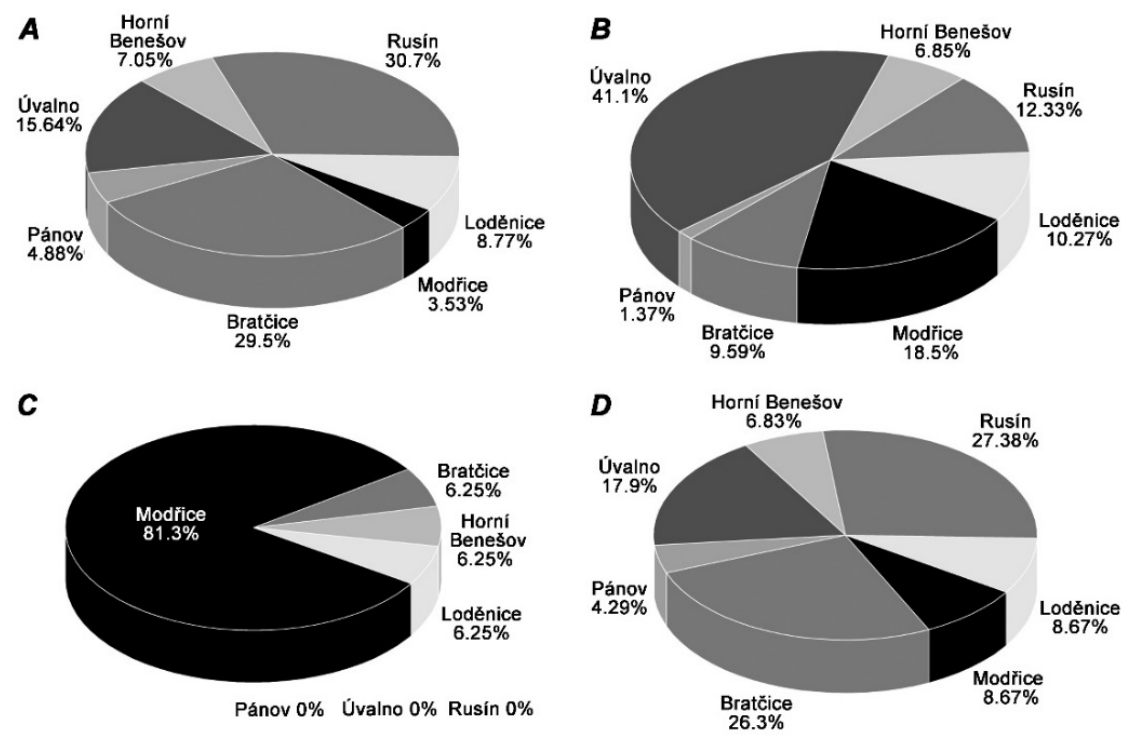

Figure 4. The most widespread genera of methanogenic microorganisms in the anaerobic digesters: Methanoculleus (A), Thermogymnomonas (B), Methanobacterium (C), total number (D). 
Within all biogas plants, the second highest diversity of thermophiles was found in Bratčice where there were 10 genera of thermophiles including Syntrophaceticus $(38.24 \%)$, Gelria $(23.53 \%)$, Thermogymnomonas $(17.65 \%)$, Oceanotoga $(10.78 \%)$, Petrotoga $(4.90 \%)$, and $0.98 \%$ of other genera including Desulfovirgula, Fervidobacterium, Moorella, Thermoactinomyces, and Thermosynthropa. The presence of Desulfovirgula and Thermosynthropa genera were determined only in the fermenter where maize silage/sugar beet pulp $(70 / 30, \mathrm{w} / \mathrm{w} \%)$ was used as a substrate. The Bratčice fermenter showed a different microbial profile with the following genera: Syntrophaceticus $(57.63 \%)$, Gelria $(15.97 \%)$, Oceanotoga $(11.11 \%)$, Thermogymnomonas (9.72\%), Fervidobacterium (2.08\%), Thermoactinomyces $(1.38 \%)$, and $0.69 \%$ of the remaining genera being Thermanaeromonas, Thermovirga, Petrotoga. The composition of the microbial consortium was fairly similar in the Pánov fermenter, most likely because both fermenters process poultry litter. However, the microbial diversity was higher in Bratčice which can be the result of different ratios of input substrates, which are maize silage/whole crop silage/poultry litter (63/31/6, w/w\%) in Bratčice and maize silage and poultry litter (92/8, w/w\%) in Pánov.

Fermenters in Úvalno and Pánov had a similar diversity of thermophiles, even though substrate heterogeneity was higher in Úvalno where sugar beet pulp, maize silage, cattle manure, whole crop silage are used compared to maize silage and poultry litter in Pánov. The lower diversity and abundance of thermophiles were detected in the Čejč fermenter (Figure 5). There were only two dominant genera, Syntrophaceticus and Thermogymnonas, in ratios of $5.27 \%$ and $94.73 \%$, respectively. In this fermenter, maize silage and liquid pig manure were used. The Loděnice and Rusín fermenters process the same substrate, sugar beet pulp and maize silage and these plants showed a similar diversity of thermophilic microorganisms with the exception of the Kosmotoga genus that was only detected in Loděnice.

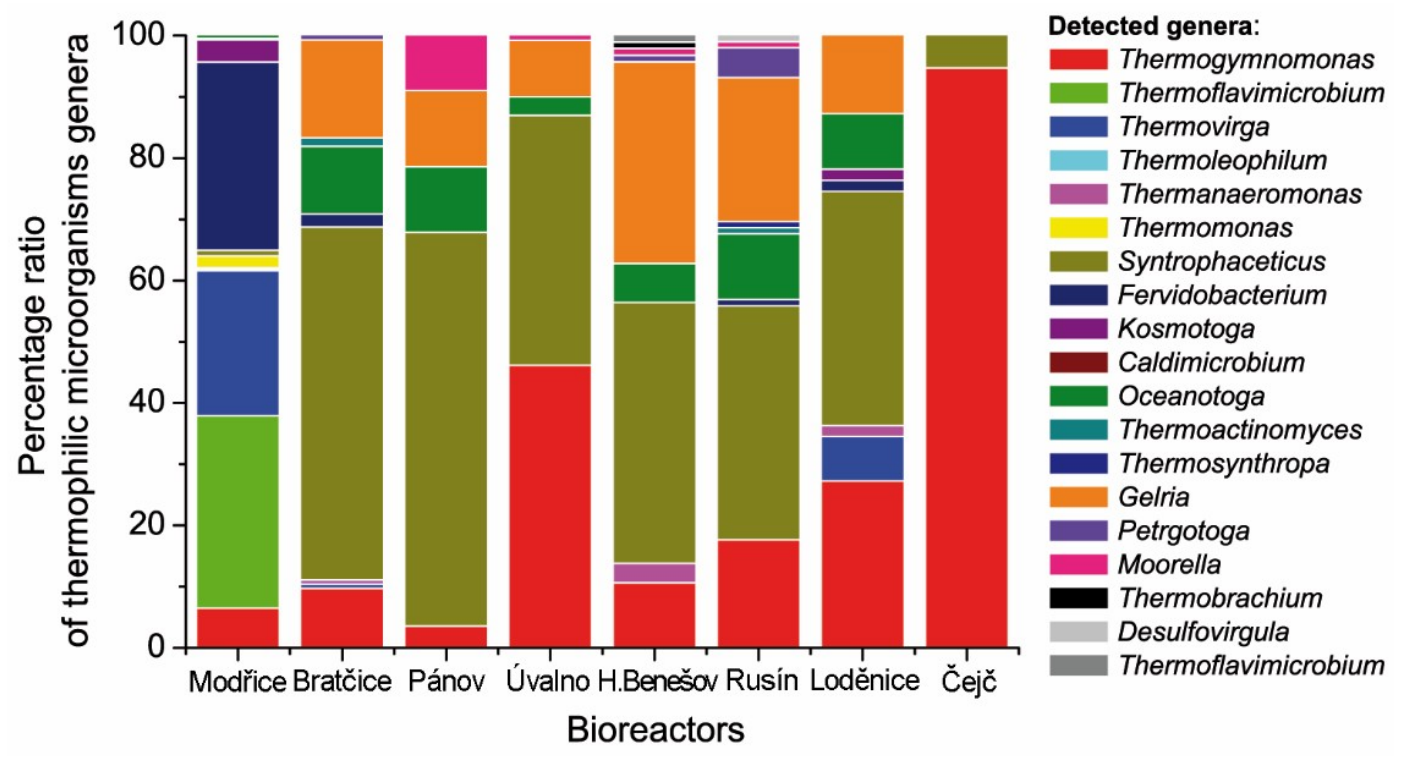

Figure 5. Percentage of each thermophilic genus in the overall population of thermophiles in each anaerobic fermenter.

Overall, Syntrophaceticus and Thermogymnomonas were the most abundant genera and were found in all anaerobic fermenters. The Gelria and Oceanotoga genera were also detected in high abundance in all fermenters with the exception of Čejč and Modřice. To clarify the genetic diversity of the thermophilic microorganisms in all these fermenters, a comparison of our $16 \mathrm{~S}$ rRNA data was performed with GenBank and the genetic relationships are shown in phylogenetic trees (Figure 6). 


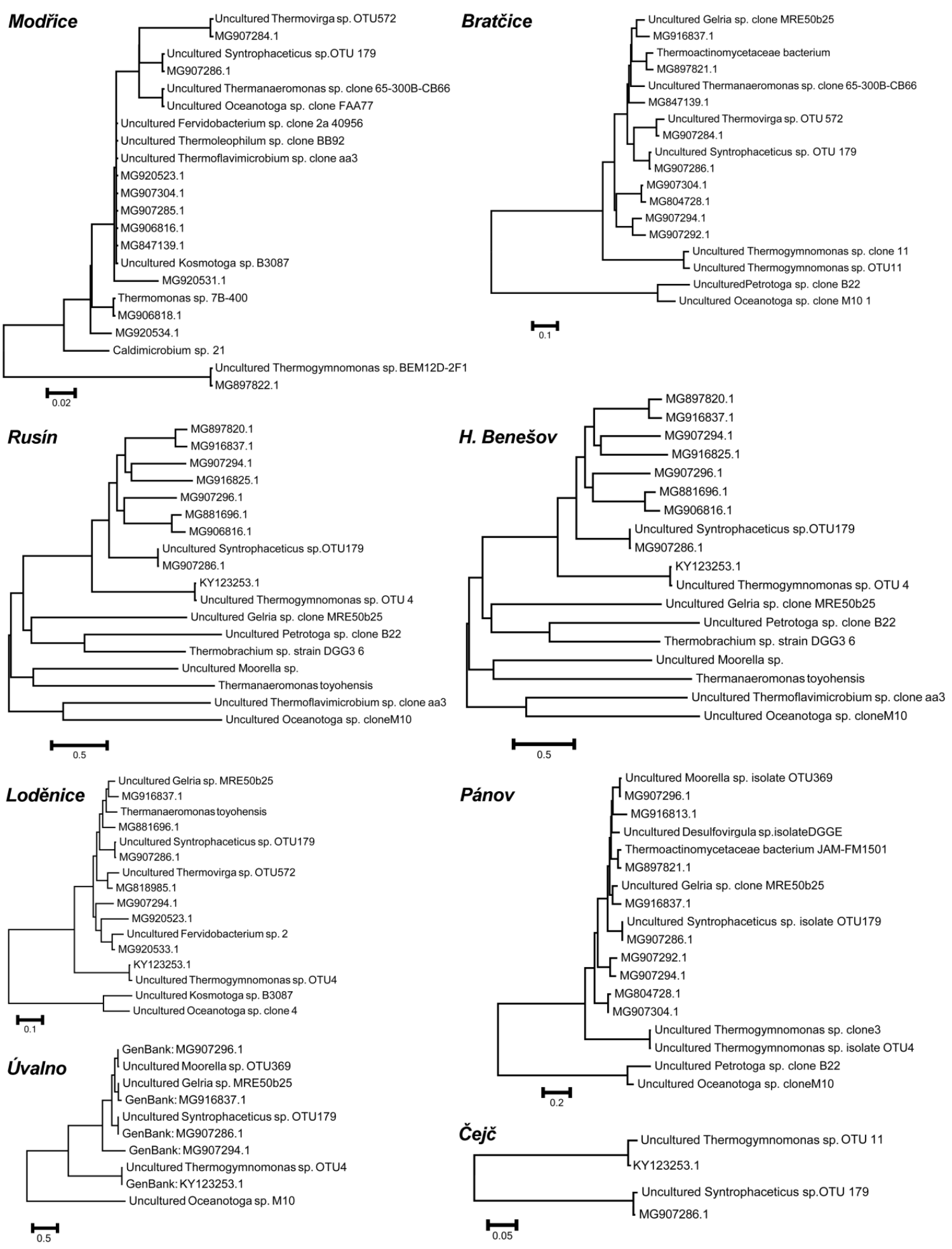

Figure 6. Phylogenetic trees showing thermophilic microorganisms found in the anaerobic fermenters.

\section{Discussion}

Biogas is the product of anaerobic fermentation and methane in biogas produced by methanogenic Archaea in the following pathways: reduction of carbon dioxide, dismutation of methanol or methylamines and fermentation of acetate [20]. Communities, which produce methane, are very resilient and stable, though they create largely undefined consortia. The aforementioned pathways can be realized by syntrophic acetate-oxidizing bacteria that convert acetate to hydrogen and carbon 
dioxide and simultaneously reduce carbon dioxide to methane by hydrogen-utilizing methanogens [20]. This process was described in thermophilic fermenters [21], mesophilic fermenters, [22] and natural environments [23,24].

Our research demonstrates that syntrophic acetate-oxidizing bacterium Syntrophaceticus sp. were the most widespread thermophilic microorganisms in all fermenters. This is probably caused by high ammonia levels leading to syntrophic acetate oxidation, a process that takes place in mesophilic fermenters [22]. The novel species Syntrophaceticus schinkii was discovered and isolated from sludge and from a mesophilic methanogenic fermenter operating at high ammonium concentrations [25,26]. Syntrophaceticus schinkii is a strictly anaerobic, mesophilic, syntrophic acetate oxidizing, spore-forming and gram-variable, bacterium with a growth temperature ranging from 25 to $40{ }^{\circ} \mathrm{C}$. Syntrophaceticus schinkii is able to oxidize acetate and produce methane during cultivation with hydrogenotrophic methanogens [25]. Another dominant genus detected in each fermenter was Thermogymnomonas. Itoh et al. (2007) isolated Thermogymnomonas acidicola and this strain was described as a thermoacidophilic, cell wall-less archaeon with variable cell size and a growth temperature range of $38-68^{\circ} \mathrm{C}$ (optimum $60^{\circ} \mathrm{C}$ ) and at $\mathrm{pH}$ value range 1.8-4.0 (optimum $\mathrm{pH}$ 3.0) [26]. This microorganism is in contrast with others we identified as it is an obligatory aerobic archeon. This genus is very often described in association with anaerobic fermentation especially when hydrolysis of cellulose occurs [27].

The other microorganisms that were also highly abundant in fermenters were from genera Gelria and Oceanotoga. One of these microorganisms Gelria glutamica was for the first time isolated and characterized from a propionate-oxidizing methanogenic enrichment culture (note that its habitat could be methanogenic granular sludge). Gelria glutamica is a strict anaerobic, moderately thermophilic, spore-forming, obligately syntrophic, glutamate-degrading, bacterium that can grow between $37^{\circ} \mathrm{C}$ and $60{ }^{\circ} \mathrm{C}$ with an optimum range from $50{ }^{\circ} \mathrm{C}$ to $55^{\circ} \mathrm{C}$ and an optimum $\mathrm{pH}$ of 7 . It can growth in cultures containing glutamate, proline, and casamino acids with the hydrogenotrophic methanogen Methanobacterium thermautotrophicum. Glutamate is transformed to $\mathrm{H}_{2}, \mathrm{CO}_{2}$, propionate and traces of succinate but sulphate, sulphite, thiosulphate, nitrate, or fumarate cannot be utilized as electron acceptors [28]. The Oceanotoga genus was found in offshore oil-production well head at Bombay High (Western India). For example, the novel Oceanotoga teriensis is a thermophilic, chemo-organotrophic bacterium which growths at a range between 25 and $70{ }^{\circ} \mathrm{C}$, with temperature optima ranging from 55 to $58{ }^{\circ} \mathrm{C}$. One of the Bacteria in this genus, Oceanotoga teriensis, utilizes various carbohydrates or complex proteinaceous substances and converts them to $\mathrm{H}_{2}, \mathrm{CO}_{2}$ and reduces thiosulfate and elemental sulfur to hydrogen sulfide [29].

Diversity of methanogenic microorganisms and their biogas production depends on the presence of other bacteria in bioreactors, including sulfate-reducing bacterial populations [11,12,30,31]. These bacteria also use organic compounds and consequently produce toxic hydrogen sulfide [32-37]. This competition and production of hydrogen sulfide in high concentration can inhibit methanogenic Archaea and acetogenic microorganisms. One of the solutions to limit this inhibition could be the use of different compounds that can impede the growth of this bacterial group and their sulfate reduction [38-42].

The microorganisms identified in the anaerobic digesters were compared with sequences from GenBank and the resulting phylogenetic trees are shown in Figure 6. The abundance and diversity of thermophilic microorganisms depend on the composition of the substrate in each fermenter. The highest microbial variation in the distribution (11 genera) and number (40.8\%) was found in the fermenter at a wastewater treatment plant. Their presence in the mesophilic anaerobic fermenters may come from the silage, where those conditions could be more than $50^{\circ} \mathrm{C}$. In this study, we identified thermophilic microorganisms in mesophilic anaerobic fermenters but it still remains unknown how physiologically or metabolically active these microorganisms were. This is a prospect for further research as here we focused on the fundamental foundations for other hypotheses and research. 


\section{Materials and Methods}

\subsection{Diversity of Biogas Plants}

The biogas fermenters were located in Úvalno, Horní Benešov, Čejč, Pánov, Modřice, Rusín, Loděnice, and Bratčice in the Czech Republic. The types of substrates are presented as the ratio of fresh input substrate ( $\mathrm{w} / \mathrm{w} \%)$. The compositions were as follows: Úvalno: maize silage, sugar beet pulp, whole crop silage, cattle manure (44/44/6/6); Horní Benešov: maize silage, sugar beet pulp, whole crop silage, cattle manure, grass silage (29/39/12/15/5); Čejč: maize silage and liquid pig manure (80/20), Pánov: maize silage, poultry litter (92/8); Modřice: primary sludge, biological sludge (50/50), Rusín: maize silage, sugar beet pulp (70/30); Loděnice: maize silage, sugar beet pulp (75/25); Bratčice: maize silage, whole crop silage, poultry litter (63/31/6). The investigated scale anaerobic digesters is presented in Table 1.

Table 1. The investigated scale anaerobic digesters.

\begin{tabular}{|c|c|c|c|c|c|c|c|c|c|}
\hline Fermenter & $\begin{array}{c}\text { Installed } \\
\text { Power } \\
\left(\mathbf{k W}_{\mathrm{el}}\right)\end{array}$ & $\begin{array}{l}\text { Fermenter } \\
\text { Volume } \\
\left(\mathrm{m}^{3}\right)\end{array}$ & $\begin{array}{c}\text { Process } \\
\text { Tempe-rature } \\
\left({ }^{\circ} \mathrm{C}\right)\end{array}$ & $\begin{array}{l}\text { Hydraulic } \\
\text { Retention } \\
\text { time }\end{array}$ & $\begin{array}{l}\text { Daily Biogas } \\
\text { production Rate } \\
\left(\mathrm{L}_{\text {biogas }} \cdot \mathrm{L}_{\text {ferm.vol. }}{ }^{-1}\right)\end{array}$ & $\begin{array}{c}\mathrm{CH}_{4} \text { Content } \\
\text { in Biogas } \\
\left(\%_{\mathrm{vol}}\right)^{*}\end{array}$ & $\begin{array}{l}\mathrm{pH} \text { in } \\
\text { Fermenter } \\
(-)^{*}\end{array}$ & $\begin{array}{c}\text { Solids } \\
\text { Content in } \\
\text { Fermenter } \\
(\%) *\end{array}$ & $\begin{array}{c}\text { Volatile Solids } \\
\text { Content in } \\
\text { Fermenter } \\
(\%) *\end{array}$ \\
\hline Modřice & 1000 & $6 \times 3000$ & 34 & 22 & 0.64 & 47 & 7.02 & 5.09 & 59.13 \\
\hline Bratčice & 750 & $\begin{array}{l}2 \times 1040 \\
1 \times 1040\end{array}$ & 40 & 86 & 2.77 & 51.5 & 8.3 & 10.16 & 75.23 \\
\hline Pánov & 500 & $\begin{array}{l}2 \times 1320 \\
1 \times 1630\end{array}$ & 41 & 85 & 1.76 & 48 & 8.03 & 10.33 & 79.46 \\
\hline Úvalno & 750 & $\begin{array}{l}2 \times 1040 \\
1 \times 1040\end{array}$ & 40 & 78 & 2.77 & 49 & 7.69 & 8.84 & 78.85 \\
\hline $\begin{array}{c}\text { Horní } \\
\text { Benešov }\end{array}$ & 750 & $\begin{array}{l}2 \times 1040 \\
1 \times 1040\end{array}$ & 41 & 85 & 2.77 & 52 & 7.85 & 7.87 & 77.52 \\
\hline Rusín & 750 & $\begin{array}{l}2 \times 1970 \\
1 \times 1630\end{array}$ & 41 & 85 & 1.56 & 48 & 7.63 & 8.52 & 79.15 \\
\hline Loděnice & 840 & $3 \times 1970$ & 41 & 90 & 1.64 & 50.5 & 7.65 & 7.9 & 78.51 \\
\hline Čejč & 750 & $\begin{array}{l}2 \times 3500 \\
1 \times 3800\end{array}$ & 40 & 65 & 0.81 & 50.3 & 7.54 & 4.3 & 78.98 \\
\hline
\end{tabular}

${ }^{*}$ Long term average.

\subsection{Sampling and Analytical Methods}

Three samples were collected from each biogas plant reactor with volumes ranging from 2500 to $3500 \mathrm{~m}^{3}$ and operated at $40 \pm 4{ }^{\circ} \mathrm{C}$. Organic load rate was 3.5-5.5 kg org. mass $/ \mathrm{m}^{3}$ per fermenter and feed intervals were $80-100 \mathrm{~kg} / \mathrm{kWhel}$. The samples were collected directly from the fermenter into sterile vessels. After collection, they were stored in thermocontainer and immediately transported to the laboratory for further analysis.

The temperature, volatile solids content, total solids (TS) content, $\mathrm{pH}$, redox potential, and biogas composition in each anaerobic digester of biogas plant was determined. TS was determined as an amount of material remaining after the water in the sample has been evaporated at $105^{\circ} \mathrm{C} \pm 5^{\circ} \mathrm{C}$ in a drying oven EcoCELL 111 (BMT Medical Technology Ltd., Brno, the Czech Republic), according to Czech Standard Method (CSN EN 14346 2007) [43]. Volatile solids content (VS) was determined as an amount of material remaining after the combustion of the samples at $550{ }^{\circ} \mathrm{C} \pm 5^{\circ} \mathrm{C}$ according to Czech Standard Method (CSN EN 15169, 2007) [44]. Muffle furnace LMH 11/12 (LAC, Ltd., Rajhrad, The Czech Republic) was used. For $\mathrm{pH}$ and redox potential measurement $\mathrm{pH} / \mathrm{Cond}$ meter 3320 (WTW $\mathrm{GmbH}$, Dinslaken, Germany) was used, in accordance with standard (CSN EN 12176, 1999) [45]. Biogas composition was estimated by the gas analyzer Dräger X-am 7000 (Dräger Safety AG\&Co. KGaA, Lübeck, Germany).

The results were analyzed and plots were built using software package Origin7.0 (www.originlab.com). Using the experimental data, the basic statistical parameters (M-mean, SE-standard error, $\mathrm{M} \pm \mathrm{SE}$ ) have been calculated. The accurate approximation was when $p \leq 0.05$ [46]. 


\subsection{DNA Isolation, Amplification, and Sequencing}

The isolation of DNA was done by the QIAamp Fast DNA Stool Mini Kit (QIAGEN GmbH, Hilden, Germany). The sample (100 mg) was washed with $1.4 \mathrm{~mL}$ of ASL buffer (QIAGEN GmbH, Hilden, Germany) and it was heated at $95{ }^{\circ} \mathrm{C}$ for $10 \mathrm{~min}$. For amplification of the V3 and V4 variable regions of the $16 \mathrm{~S}$ rRNA gene fragments universal primers were used [47]. The primers were marked by molecular barcodes for sample identification. Maxima ${ }^{\mathrm{TM}}$ Probe $\mathrm{qPCR}$ Master Mix (Thermo Fisher Scientific, Waltham, MA, USA), was used for PCR reaction. All manipulations of amplification and sequencing were carried out as described in previous paper [12,48]. Based on the microorganisms' presence, the calculation of relative abundance of the taxonomic groups was done. Sequences analysis was done by NCBI and by BLAST [49]. The genomic sequences are available in GenBank, access No.: MG916813.1, MG847139.1, MG906816.1, MG907296.1, MG920534.1, MG897820.1, MG920523.1, MG920523.1, MG907286.1, MG920533.1, MG907285.1, MG920531.1, MG916837.1, MG907284.1, MG907294.1, MG881696.1, MG818985.1, MG907292.1, MG916825.1, MG906818.1, KY123356.1, MG897821.1, MG907304. The sequences were processed by Geneious 7.1.9 and genomic analysis was performed [50]. Alignments of sequences were done by MEGA7 using Clustal W with the BLOSUM cost matrix, and clustered by the neighbor-joining method [51]. The results were processed and analyzed using Origin 7.0 (www.origin-lab.com).

\section{Conclusions}

Thermophilic microorganisms were characterized from various biogas plant fermenters and their diversity and abundance were determined under the effect of various input substrates and operating conditions. The presence of the different thermophiles is connected to the substrate profiles of the biogas plants investigated which may be due to an extended range of temperature response for these thermophiles. The study is providing important information considering thermophiles and methanogens that can help to better optimize biogas production. In addition, we highlight the impact of different input substrates and their influence on the diversity and the abundance of microorganisms present. Taken as a whole, this study gives a broader and clearer picture of the processes occurring in mesophilic biogas reactors in the presence of thermophiles.

Author Contributions: I.K. conceived and contributed to the writing of the paper, together with M.V. and T.V.; I.K. designed and performed the experiments; J.C. and T.V. analyzed the data and optimized the process parameters; T.V. performed analysis of the data and validation of the results; J.C., D.D., and Y.B. contributed to the writing and the final design of the paper. All authors have read and agreed to the published version of the manuscript.

Funding: This study was supported by Grant Agency of the Masaryk University (MUNI/A/0902/2018). Funding was also provided by the Center for Bioenergy Innovation (CBI), a U.S. Department of Energy Bioenergy Research Center supported by the Office of Biological and Environmental Research in the DOE Office of Science.

Acknowledgments: This work was authored in part by Alliance for Sustainable Energy, LLC, the manager and operator of the National Renewable Energy Laboratory for the U.S. Department of Energy (DOE) under Contract No. DE-AC36-08GO28308. The views expressed in the article do not necessarily represent the views of the DOE or the U.S. Government.

Conflicts of Interest: The authors declare no conflict of interest.

\section{References}

1. Griffin, M.E.; McMahon, K.D.; Mackie, R.I.; Raskin, L. Methanogenic population dynamics during start-up of anaerobic digesters treating municipal solid waste and biosolids. Biotechnol. Eng. 2000, 57, 342-355. [CrossRef]

2. Grothenhuis, J.T.; Smith, M.; Plugge, C.M.; Yuansheng, X.; Lammeren, A.A.; Stams, A.J. Bacteriological composition and structure of granular sludge adapted to different substrates. Appl. Environ. Microbiol. 1991, 57, 1942-1949.

3. Ilyin, V.K.; Korniushenkova, I.N.; Starkova, L.V.; Lauriniavichius, K.S. Study of methanogenesis during bioutilization of plant residuals. Acta Astronaut. 2005, 56, 465-470. [CrossRef] [PubMed] 
4. Jäckel, U.; Thummes, K.; Kämpfer, P. Thermophilic methane production and oxidation in compost. FEMS Microbiol. Ecol. 2005, 52, 175-184. [CrossRef]

5. Sreekrishnan, T.R.; Kohli, S.; Rana, V. Enhancement of biogas production from solid substrates using different techniques-A review. Bioresour. Technol. 2004, 95, 1-10.

6. Krich, K.; Augenstein, D.; Batmale, J.P.; Benemann, J.; Rutledge, B.; Salour, D. Biomethane from Dairy Waste: A Sourcebook for the Production and Use of Renewable Natural Gas in California; USDA Rural Development: Washington, DC, USA, 2005.

7. Conrad, R. Contribution of hydrogen to methane production and control of hydrogen concentration in methanogenic soils and sediments. FEMS Microbiol. Ecol. 1999, 28, 193-202. [CrossRef]

8. Demirel, B.; Scherer, P. The roles of acetotrophic and hydrogenotrophic methanogens during anaerobic conversion of biomass to methane: A review. Rev. Environ. Sci. Biotechnol. 2008, 7, 173-190. [CrossRef]

9. Wilkie, A. Biomethane from Biomass. In Biowaste and Biofuels; Harwood, C., Demain, A., Eds.; ASM Press: Washington, DC, USA, 2008; pp. 195-205.

10. Ahring, B.; Ibrahim, A.A.; Mladenovska, Z. Effect of temperature increase from 55 to $65{ }^{\circ} \mathrm{C}$ on performance and microbial population dynamics of an anaerobic reactor treating cattle manure. Water Resour. 2001, 35, 2446-2452. [CrossRef]

11. Kushkevych, I.; Vítězová, M.; Vítěz, T.; Bartoš, M. Production of biogas: Relationship between methanogenic and sulfate-reducing microorganisms. Open Life Sci. 2017, 12, 82-91. [CrossRef]

12. Kushkevych, I.; Kováč, J.; Vítězová, M.; Vítěz, T.; Bartoš, M. The diversity of sulfate-reducing bacteria in the seven bioreactors. Arch. Microbial. 2018, 200, 945-950. [CrossRef]

13. Ziemiński, K.; Frąc, M. Methane fermentation process as anaerobic digestion of biomass: Transformations, stages and microorganisms. Afr. J. Biotechnol. 2012, 11, 4127-4139.

14. Scherer, P.A.; Vollmer, G.R.; Fakhouri, T.; Martensen, S. Development of methanogenic process to degrade exhaustively the organic fraction of municipal grey waste under thermophilic and hyperthermophilic conditions. Water Sci. Technol. 2000, 41, 83-91. [CrossRef] [PubMed]

15. Schink, B. Energetics of syntrophic cooperation in methanogenic degradation. Microbiol. Mol. Biol. Rev. 1997, 61, 262-280. [PubMed]

16. Weiland, P. Biogas production: Current state and perspectives. Appl. Microbiol. Biotechnol. 2010, 85, 849-860. [CrossRef] [PubMed]

17. Madigan, M.T.; Martino, J.M.; Thomas, D.B. Brock Biology of Microorganisms; Pearson Prentice Hall: Upper Saddle River, NJ, USA, 2006.

18. Stetter, K. History of discovery of the first hyperthermophiles. Extremophiles 2006, 10, 357-362. [CrossRef] [PubMed]

19. Satyanarayana, T.; Littlechild, J.; Kawarabayasi, Y. Thermophilic Microbes in Environmental and Industrial Biotechnology. Biotechnol. Thermophiles 2013, 3. [CrossRef]

20. Barker, H.A. On the biochemistry of methane fermentation. Arch. Microbiol. 1936, 7, 404-419. [CrossRef]

21. Zinder, S.H.; Koch, M. Non-aceticlastic methanogenesis from acetate: Acetate oxidation by a thermophilic syntrophic coculture. Arch. Microbiol. 1984, 138, 263-272. [CrossRef]

22. Schnurer, A.; Houwen, F.P.; Svensson, B.H. Mesophilic syntrophic acetate oxidation during methane formation by a triculture at high ammonium concentration. Arch. Microbiol. 1994, 162, 70-74. [CrossRef]

23. Nazina, T.N.; Shestakova, N.M.; Grigor'yan, A.A.; Mikhailova, E.M.; Tourova, T.P.; Poltaraus, A.B.; Feng, C.; Ni, F.; Belyaev, S.S. Phylogenetic diversity and activity of anaerobic microorganism of high-temperature horizons of the Dagang oilfield (P. R. China). Microbiology 2006, 75, 70-81. [CrossRef]

24. McInerney, M.J.; Struchtemeyer, C.G.; Sieber, J.; Mouttaki, H.; Stams, A.J.M.; Schink, B.; Rohlin, L.; Gunsalus, R.P. Physiology, ecology, phylogeny and genomics of microorganisms capable of syntrophic metabolism. Ann. N. Y. Acad. Sci. USA 2008, 1125, 58-72. [CrossRef] [PubMed]

25. Westerholm, W.; Roos, S.; Schnurer, A. Syntrophaceticus schinkii gen. nov. sp. nov., an anaerobic, syntrophic acetate-oxidizing bacterium isolated fromamesophilic anaerobic filter. FEMS Microbiol. Lett. 2010, 309, 100-104. [PubMed]

26. Itoh, T.; Yoshikawa, N.; Takashina, T. Thermogymnomonas acidicola gen. nov. sp. nov. a novel thermoacidophilic, cell wall-less archaeon in the order Thermoplasmatales, isolated from a solfataric soil in Hakone, Japan. Int. J. Syst. Evol. Microbiol. 2007, 57, 2557-2561. [CrossRef] [PubMed] 
27. Dong, P.; Li, L.; Zhen, F.; Kong, X.; Sun, Y.; Zhang, Y. Comparison of dry and wet milling pretreatment methods for improving the anaerobic digestion performance of the Pennisetum hybrid. RSC Adv. 2017, 7/21, 12610-12619.

28. Plugge, C.M.; Balk, M.; Zoetendal, E.G.; Stams, A.J. Gelria glutamica gen. nov. sp. nov. a thermophilic, obligately syntrophic, glutamate-degrading anaerobe. Int. J. Syst. Evol. Microbiol. 2002, 52, 401-407. [CrossRef] [PubMed]

29. Jayasinghearachchi, H.S.; Lal, B. Oceanotoga teriensis gen. nov., sp. nov., a thermophilic bacterium isolated from offshore oil-producing wells. Int. J. Syst. Evol. Microbiol. 2011, 61, 554-560. [CrossRef] [PubMed]

30. Kushkevych, I.; Vítězová, M.; Fedrová, M.; Vochyanová, Z.; Paráková, L.; Hošek, J. Kinetic properties of growth of intestinal sulphate-reducing bacteria isolated from healthy mice and mice with ulcerative colitis. Acta Vet. Brno 2017, 86, 405-411. [CrossRef]

31. Kushkevych, I.; Vítězová, M.; Vítěz, T.; Kováč, J.; Kaucká, P.; Jesionek, W.; Bartoš, M.; Barton, L. A new combination of substrates: Biogas production and diversity of the methanogenic microorganisms. Open Life Sci. 2018, 13, 119-128. [CrossRef]

32. Kushkevych, I.V. Kinetic Properties of Pyruvate Ferredoxin Oxidoreductase of Intestinal Sulfate-Reducing Bacteria Desulfovibrio piger Vib-7 and Desulfomicrobium sp. Rod-9. Pol. J. Microbiol. 2015, 64, 107-114. [CrossRef]

33. Kushkevych, I.; Fafula, R.; Parak, T.; Bartos, M. Activity of $\mathrm{Na}^{+} / \mathrm{K}^{+}$-activated $\mathrm{Mg}^{2+}$-dependent ATP hydrolase in the cell-free extracts of the sulfate-reducing bacteria Desulfovibrio piger Vib-7 and Desulfomicrobium sp. Rod-9. Acta Vet. Brno 2015, 84, 3-12. [CrossRef]

34. Kushkevych, I.V. Activity and kinetic properties of phosphotransacetylase from intestinal sulfate-reducing bacteria. Acta Biochim. Pol. 2015, 62, 1037-1108. [CrossRef] [PubMed]

35. Kushkevych, I.; Dordević, D.; Vítězová, M. Analysis of pH dose-dependent growth of sulfate-reducing bacteria. Open Med. 2019, 14, 66-74. [CrossRef] [PubMed]

36. Kushkevych, I.; Dordević, D.; Vítězová, M. Toxicity of hydrogen sulfide toward sulfate-reducing bacteria Desulfovibrio piger Vib-7. Arch. Microbiol. 2019, 201, 389-397. [CrossRef] [PubMed]

37. Kushkevych, I.; Kobzová, E.; Vítězová, M.; Vítěz, T.; Dordević, D.; Bartoš, M. Acetogenic microorganisms in operating biogas plants depending on substrate combinations. Biologia 2019, 74, 1229-1236. [CrossRef]

38. Kushkevych, I.; Kollar, P.; Suchy, P.; Parak, K.; Pauk, K.; Imramovsky, A. Activity of selected salicylamides against intestinal sulfate-reducing bacteria. Neuroendocrinol Lett. 2015, 36, 106-113.

39. Kushkevych, I.; Kollar, P.; Ferreira, A.L.; Palma, D. Antimicrobial effect of salicylamide derivatives against intestinal sulfate-reducing bacteria. J. Appl. Biomed. 2016, 14, 125-130. [CrossRef]

40. Kushkevych, I.; Vítězová, M.; Kos, J.; Kollár, P.; Jampílek, J. Effect of selected 8-hydroxyquinoline-2-carboxanilides on viability and sulfate metabolism of Desulfovibrio piger. J. App. Biomed. 2018, 16, 241-246. [CrossRef]

41. Kushkevych, I.; Dordević, D.; Kollar, P. Analysis of physiological parameters of Desulfovibrio strains from individuals with colitis. Open Life Sci. 2018, 13, 481-488. [CrossRef]

42. Kushkevych, I.; Dordević, D.; Vítězová, M.; Kollar, P. Cross-correlation analysis of the Desulfovibrio growth parameters of intestinal species isolated from people with colitis. Biologia 2018, 73, 1137-1143. [CrossRef]

43. CSN EN 14346 Characterization of Waste-Calculation of Dry Matter by Determination of Dry Residue or Water Content; Czech Standards Institute: Prague, Czech Republic, 2007.

44. CSN EN 15169 Characterization of Waste-Determination of Loss on Ignition in Waste, Sludge and Sediments; Czech Standards Institute: Prague, Czech Republic, 2007.

45. CSN EN 12176 Characterization of Sludge-Determination of $p H$-value; Czech Standards Institute: Prague, Czech Republic, 1999.

46. Bailey, N.T.J. Statistical Methods in Biology; Cambridge University Press: Cambridge, UK, 1995.

47. Nossa, C.W.; Oberdorf, W.E.; Yang, L.; Aas, J.A.; Paster, B.J.; Desantis, T.Z. Design of 16S rRNA gene primers for 454 pyrosequencing of the human foregut microbiome. World J. Gastroenterol. 2010, 16, 4135-4144. [CrossRef]

48. Caporaso, J.G.; Kuczynski, J.; Stombaugh, J. QIIME allows analysis of high-throughput community sequencing data. Nat. Methods 2010, 7, 335-336. [CrossRef] [PubMed]

49. Altschul, S.F.; Gish, W.; Mille, W.; Myers, E.W.; Lipman, D.J. Basic local alignment search tool. J. Mol. Biol. 1990, 215, 403-410. [CrossRef] 
50. Kearse, M.; Moir, R.; Wilson, A.; Stones-Havas, S.; Cheung, M.; Sturrock, S. Geneious Basic: An integrated and extendable desktop software platform for the organization and analysis of sequence data. Bioinformatics 2012, 28, 1647-1649. [CrossRef] [PubMed]

51. Larkin, M.A.; Blackshields, G.; Brown, N.P.; Chenna, R.; McGettigan, P.A.; McWilliam, H. Clustal W and Clustal X version 2.0. Bioinformatics 2007, 23, 2947-2948. [CrossRef]

(C) 2019 by the authors. Licensee MDPI, Basel, Switzerland. This article is an open access article distributed under the terms and conditions of the Creative Commons Attribution (CC BY) license (http://creativecommons.org/licenses/by/4.0/). 